\title{
FORMATION AND ROLE OF THE MANCHETTE MICROTUBULES IN THE POULTRY SPERMATIDS
}

\author{
M. MARETTA \\ Department of Anatomy and Histology, University of Veterinary Medicine, 04181 Košice, Slovakia
}

Received October 31, 1994r

Accepted March 30, 1995

\begin{abstract}
M a r e t t a M.: Formation and Role of the Manchette Microtubules in the Poultry Spermatids. Acta vet. Brno 1995, 64: 000-000.

Formation of the manchette microtubules and its disappearance in spermatids of cocks, drakes and Japanese quail was studied.

The manchette in spermatid of three species examined was formed by a set of microtubules appearing close to the elongating spermatid nucleus. It assumed two shapes: in the first stage of development, it is helical-shaped, and in the second stage it has longitudinally-arranged microtubules. In both cases, microtubules are arranged in the shape of a cylinder, the integrity of which could be distorted, above all, in the region of the flagellum. At the helical arrangement, the manchette consists of one row of helically running microtubules that start in the forming acrosome region and terminate at the end of a distal centriole of developing flagellum. The manchette with its longitudinal-shaped microtubules also starts in the region of the acrosome, however, it encroaches the end compartment of the forming flagellum. Conversion of the helical-shaped microtubules into the longitudinal arrangement is very fast, and is likely to occur by reconstruction of original microtubules as well as synthesis of new ones. The manchette dissapp ears by disintegration of all microtubules without leaving any residue from the region of the head and anterior part of the flagellum, and by leaving the residue of electron-dense material in the cytoplasm of a maturing spermatid. The role of the manchette with helical-arranged microtubules is to model the nucleus from originally spherical shape to a long cylinder, and with longitudinal arrangement of microtubules, it displaces the cytoplasm from the anterior part of the head to the caudal part of the flagellum. The manchette is suggested to play also a role in formation of a mitochondrial sheath of the sperm flagellum.
\end{abstract}

Microtubules, manchette, formation, role, spermatids, poultry

The manchette of the spermatid is a transient organelle composed of numerous microtubules located and running mostly uniformly close to the nucleus. It appears just prior to the onset of chromatin condensation and in mammals it encircles the caudal pole of the nucleus and extends into the postnuclear cytoplasm. B u r $\mathrm{g}$ o $\mathrm{s}$ and $\mathrm{F} \mathrm{a} \mathrm{w} \mathrm{c} \mathrm{e} \mathrm{t} \mathrm{t}$ (1955) observed the beginnings of the manchette development in the period of forming of the acrosomal cap and migration of the Golgi apparatus, when at the caudal pole of the nucleus a higher number of fine filaments appear in the surrounding cytoplasm. According to D o o h e r and B e $n \mathrm{n}$ e $\mathrm{t}$ (1973), P 1 ö e n (1971), and S i c k l e s and $\mathrm{H}$ e a t h (1986) the manchette tubules originate in a ring-shaped structure that appears just under the posterior margin of the acrosomal cap. B rö ke l m a n n (1963), G o o d r o w e and He a th (1984), R u s s ell et al. (1991) observed the same site from which the manchette microtubules originated.

F a w c e t t et al. (1971) found that the manchette is embedded in dense fibrillar material that occupies the concave surface of the nuclear ring, and microtubules are the same and straight in their entire course.

M c I n t o s h and P o r t e r (1967) dealt with formation, role and structure of the manchette in rooster spermatids. They characterized the manchette as a helix consisting of two microtubules encircling the spermatid nucleus. When elongation of the nucleus is finished, the helical-arranged microtubules disappear and they are replaced with a new group of microtubules closely adjacent to the nucleus and running in parallel to the long axis of the head. A similar structure of the manchette has also been described in pigeon ( $\mathrm{F} \mathrm{a} \mathrm{w} \mathrm{c} \mathrm{e} \mathrm{tt} \mathrm{et} \mathrm{al.} \mathrm{1971).}$

The aim of the present paper is to describe the formation of the manchette, its transformation and disappearance in cocks, drakes and Japanese quail spermatids. The possible role of the manchette is analysed. 


\section{Materials and Methods}

For the study, testes of 5 cocks, 4 drakes and 4 male Japanese quail were used at the time of their full sexual activity. Excisions were taken from killed animals. Glutaraldehyde $(2.5 \%)$ and $\mathrm{OsO}_{4}(1 \%)$ were used for fixation. Both fixatives were diluted with $0.2 \mathrm{M}$ phosphate buffer, $\mathrm{pH}$ 7.2. Fixation in both solutions lasted 1 to 2 hours, and after each fixation, the samples were rinsed in $0.2 \mathrm{M}$ phosphate buffer and then dehydrated in an increasing acetone series. Dehydrated samples were embedded in Durcupan ACM. Ultrathin sections were cut by ultramicrotome Tesla BS $490 \mathrm{~A}$, and stained with water solution of uranylacetate and lead citrate ( $\mathrm{R} \mathrm{e} \mathrm{y} \mathrm{n} \mathrm{o} 1 \mathrm{~d} \mathrm{~s}$ 1963). Stained sections were examined in electron microscope Tesla BS 613.

\section{Results}

The onset of the manchette development as an organ modelling the spermatid nucleus coincided with the period, when the acrosome began to be formed in all three avian species under study: At the beginning of its formation, several microtubules appeared near the nucleus that was spherical at that time. During further development, when the spermatid acquired an elongated shape in the acrosome region, the number of microtubules increased and they appeared separately as well as in groups.

In our material, aggregation of a larger number of microtubules near the nucleus was accompanied by a pronounced local constriction of the nucleus ( Plate VII., Fig. 1), which was observed, above all, in the spermatids of Japansese quail and less in those of cocks and drakes. Some microtubules were organized in a regular way next to each other, and others ran irregularly in various directions (Plate VIII., Fig. 2). A larger aggregation of microtubules was observed in the caudal part of the nucleus, where a pronounced accumulation of the microtubules oriented in various directions close to the centriole complex (Fig. 3) was observed, too. As the elongation of spermatid nucleus proceeded, condensation of chromatin occurred and it adopted a fine granular character. A larger accumulation of microtubules at several places near the nucleus caused its marked narrowing (Plate IX., Fig. 4).

The process of the microtubule appearance close to the nucleus is very rapid. During their development, the microtubules were more and more located in one continual row so that the spermatid nucleus acquired the shape of a cylinder. In cross-section, these microtubules appeared as a circular ring (Fig. 5). After studying more cross-sections, it was evident that microtubules were arranged helically in all three species. This helix of microtubules started under the acrosomal cap (Plate X., Fig. 6), encircled the whole nucleus, and extended up to the end of the distal centriole in the posterior region of the spermatid (Plate XI., Fig. 7). In this part, the manchette preserved its cylindrical shape, thus having such a course as that in the proximal part at the point where it encircled the nucleus.

During further development, the helical course of the microtubules of the manchette was replaced by a system of microtubules oriented in parallel to the long axis of the nucleus and flagellum (Plate XI., Fig. 8, Plate XII., Fig. 9). Conversion of helical microtubules into the longitudinal ones was presumably rapid in all three species under study, since we failed to detect the stage of this conversion in neither of them. In our study, it was not possible to find whether and how do the helical microtubules participate in formation of the manchette with longitudinal microtubules. The initial helical form is supposed to be distorted and replaced with a longitudinal one, in construction of which the helical microtubules are also involved. The microtubules of the longitudinally shaped manchette began, as those of the helix-shaped manchette, in the acrosomal cap region and ran very close to the nucleus (Fig. 10) preserving a parallel direction to the nuclear axis also in the future flagellum region (Fig. 11). The wall thickness of this cylinder is given by the number of microtubules at a respective point. Their number at one point used to be variable ranging from 2 to 5 microtubules. The total number of microtubules in a cross-section was rather variable and ranged from 140 to 180 . The greater difference in the number of microtubules was observed, above all, in the flagellum 
region, at the time when mitochondria attached to the developing flagellum. It was not possible to assess the length of microtubules in no one of species studied due to the fact that practically no section along the entire length of microtubules can be made. However, they seemed to run to a considerable distance of the head length. Changes in thickness of the logitudinally arranged microtubules have been observed, and it usually ranged about $35 \mathrm{~nm}$. Caudally these microtubules moved as far as beyond the nucleus - into cytoplasmic protrusions (Plate XIII., Fig. 12). Arrangement of the microtubules moving longitudinally was no more as regular as that in the manchette with helically arranged microtubules, but also in this case, they formed a continual cylinder along the entire course of the nucleus. At some point, this cylinder was not so continual due to the absence of microtubules. The microtubule absence has been observed especially in the flagellum region, above all, in the spermatid in an advanced stage of development. Organization of the longitudinally arranged microtubules, as was the case with their helical arrangement, has not been observed. Only a limited irregular accumulation of the microtubules was found. During the late stage of the spermatid maturation a remarkable event seemed to be the deposition of electron-dense material very close to the centrioles of cocks, above all in the flagellum region. Deposition of this dense material coincided with the time of appearance of the mitochondrial and amorphous sheath and release of the flagellum from the cytoplasm encirclement.

After fulfilling its function the manchette disappears. The beginning of this process was observed at the time, when mitochondria were moving from the anterior part of the spermatid to the point where the mitochondrial sheath would be formed. In the proximal part near the nucleus and near the future central point of the flagellum, the microtubules of the manchette are disintegrated without any residues. The microtubules of the manchette at the flagellum site disappeared first near the mitochondria located near the forming flagellum (Fig. 8). In the region of amorphous sheath of the flagellum and more caudally mirotubules disappeared, however, leaving a small amount of electron-dense material (Plate XIII., Figs. 12, 13) that was later degraded together with remnants of cytoplasmic protrusions.

\section{Discussion}

Formation of the manchette and origin of the microtubules have not been fully elucidated as yet. B o i s s o $\mathrm{n}$ and $\mathrm{M}$ a $\mathrm{t} \mathrm{t} \mathrm{e} \mathrm{i}$ (1966) suggested that microtubules arise from the nuclear membrane. In some species of invertebrates, granular material occurring near the centrioles is considered as that forming microtubules (A $\mathrm{n} \mathrm{de} \mathrm{r} \mathrm{s} \mathrm{o} \mathrm{n}$ and E 11 i s 1967).

In our work, the first appearance of microtubules was observed in cocks, drakes and Japanese quail at the time of the acrosomal cap formation. We suppose that the microtubules of the manchette arise de novo by polymerization from the material occurring in the cytoplasm. Emergence of microtubules and formation of the manchette are extremely rapid. These our findings are in agreement with data reported by M c I n t o s h and P o r t e r (1967) in the cock spermatid. This assumption is also confirmed by the fact that spermatids were found either at the beginning of manchette formation or as late as in the stage after manchette formation along the whole circumference of the nucleus.

Arrangement of the manchette microtubules is not uniform in all species. Whereas the microtubules of mammalian spermatids are oriented obliquely or longitudinally from the beginning (B r ö k e l m a n n 1963; F a w c e t t et al. 1971), in poultry they are first helical and only then longitudinal (M c In to $\mathrm{h}$ and P or te r 1967; C l a rk 1967; M a r e t t a 1974). The initial point of microtubule formation in mammalian spermatids is at the nuclear ring site (P l ö e n 1971; D o o h e r and B e n n e t t 1973). In the poultry spermatids there is no such ring present, and their initial point is the caudal margin of the acrosomal cap. $\mathrm{N}$ a g a n o (1962) observed at this point the presence of electronoptically dense granules that 
might correspond to the nuclear ring. However, neither in our material nor in that of other authors similar granules have been observed ( $\mathrm{T}$ i $\mathrm{n} \mathrm{g}$ a $\mathrm{r}$ i 1973; $\mathrm{O} \mathrm{k} \mathrm{a} \mathrm{m} \mathrm{u} \mathrm{r} \mathrm{a} \mathrm{and}$ $\mathrm{N}$ is h i y a m a 1976).

We failed to find whether the manchette with helically arranged microtubules in all species examined is a real helix or whether it is formed by independent annula located just next to each other. Mc I $n$ t o s h and P or t e r (1967) assume that it is formed by two helically twisting microtubules. We incline to this opinion considering that some microtubules exhibited an oval shape in the longitudinal sections. This would indicate their helical course. Conversion of the manchette microtubules with helical arrangement to longitudinal one is as rapid as the manchette formation. These our findings are also confirmed by Mc In $t o s h$ and P o r t e r (1967). The course of this conversion, however, is not fully known. In our opinion, this change takes place by disintegration of the microtubules with helical course in short units that are reorganized in longitudinal direction. In this process, probably the same microtubules are involved as those forming the helix. However, the opinion of $\mathrm{Cl}$ a r k (1967) cannot be excluded. He reported that this change is carried out by change in the inclination of the manchette microtubules with helical course.

Even if the question of formation and reorganization or function of the manchette has not been fully elucidated, this stage of the manchette existence may be observed in cocks, drakes and quaie. There are also, though often hypothetical, more literature data available. The question of the manchette disappearance remains largely unanswered. Most authors confirming the manchette presence in spermatids, reported that it disappears in the last stage of the spermatid maturation leaving no remnants (W e r $\mathrm{n}$ e $\mathrm{r} 1965$; R e g e r 1967). A part of the manchette is preserved only in the spermatozoa of some invertebrate species ( $\mathrm{S}$ il v e i r a and P o r t e r 1964; R o s a r i o 1964). On the other hand, manchette remnants were observed in the form of tubular elements in a protoplasmic drop and in a residual body, and they were considered as a potential remnant of the manchette (B lo o m and N i c a n d e r 1961). The manchette in the species observed in our study disappears either by disintegration of the microtubules with no remnants or by disintegration with remnants in the form of granular material. While the later disappearance of the manchette takes place in the lowest part of the cytoplasmic protrusions, the former one takes place in the upper parts of the manchette, especially in the region above the Jensen annulus. The microtubules undergoing disintegration, exhibit a loss of their integrity, i.e.their tubular shape. Deformity of the microtubules is only the first step in their complete disintegration. The unanswered question remains whether the material formed by disintegration of microtubules becomes unnecessary for the cell, or whether it is reused for construction of other cellular structures.

Many authors suggest that change of the nuclear shape during spermiogenesis is induced by external forces ( $\mathrm{R}$ u s s e $1 \mathrm{l}$ et al. 1991). This opinion is supported by the fact that the manchette appears just before onset of nuclear condensation, persists during conversion of the nuclear shape and disappears after the nucleus attained its final form. Based on topographic relations of the manchette to the nucleus in numerous animal species, $\mathrm{F}$ a w $\mathrm{c}$ e $\mathrm{t}$ t et al. (1971) concluded that the microtubules of the manchette are not directly connected with the nucleus modelling. They give several reasons for rejection of the direct participation of microtubules in nuclear morphogenesis. In the early stages of nuclear elongation in the mammalian spermatids, there are no circumferentially oriented microtubules, thus, they cannot elongate the nucleus by constriction as it is, e.g. in roosters (Mc I $\mathrm{t}$ o s $\mathrm{h}$ and P o r t e r 1967) or in reptiles ( $\mathrm{Cl}$ a r k 1967). Although longitudinally oriented microtubules are present in most species studied by F a w c e $t \mathrm{t}$ et al. (1971), the manchette appears only in the caudal nuclear part, whereas the most characteristic features of head shape are in the anterior portion of the nucleus and in the acrosome. During the period when the manchette is present in the posterior pole of the condensed nucleus, its microtubules are not in actual contact with the nucle- 
us. Moreover, the nuclear membrane is separated from the condensed chromatin by a clear zone in all species examined. It may be supposed that if the microtubules compressed the nuclear membrane they should be in its close vicinity. Observations of $\mathrm{S} \mathrm{t} \mathrm{a} \mathrm{n} l \mathrm{e}$ y (1971) in spermatids of the fish Ologocottus provide evidence against this role. Here, the nucleus remains spherical, while the chromatin becomes condensed into flattened bands against the inner nuclear membrane near to the neck region. The direct association of the manchette microtubules with the nucleus by bridges in the spermatids of rodents was shown by $\mathrm{R} \mathrm{u} \mathrm{s} \mathrm{s}$ e l et al. (1991).

Chromatin becomes highly condensed and has largely acquired its definitive shape before the nuclear membrane changes its spherical shape. This happens without participation of microtubules in each of the species studied. The spermatozoon head in the great majority of mammalian species is flattened laterally, and it is difficult to imagine a contractile role of the manchette microtubules arranged symetrically and oriented in parallel to the long axis of the acrosome. The plane of nuclear flattening is independent of the orientation of the manchette; it has been demostrated in the study of spermiogenesis of the opossum Caluromis ( $\mathrm{P} \mathrm{h}$ i 1 i p s 1970). Their spermatozoon head is discoid whereas the arrangement of the manchette microtubules is the same as in other species. In this case it is clear that the mechanism of the manchette which could contribute to a characteristic shape of the head is absent. It is obvious that spermatozoon head shape is subject to genetic control and that it is species specific.

Although F a w c e t t et al. (1971) have brought indisputable evidence of other factors influencing shape modeling of the spermatid nucleus, denying direct participation of the manchette microtubules, this evidence cannot be fully applied to poultry. Our results (M a r e t t a 1974) as well as those of others (Mc I $\mathrm{t} \mathrm{tos} \mathrm{h}$ and P o t t e r 1967) confirm the indisputable participation of the manchette with helically arranged microtubules in the conversion of spherical shape of the nucleus to the elongated cylinder.

It has not been fully elucidated whether the manchette with helically oriented microtubules has some other roles besides that in the nuclear shape modelling. Such arrangement of microtubules may have, in addition to nuclear elongation, also other roles. We found that the manchette with helically arranged microtubules is not limited only to the nucleus, but exceeds considerably beyond its caudal margin, reaching a half length of the transformed distal centriole or farther while the course of microtubules in this region is similar to that near the nucleus. The role of the manchette with helical microtubules at modeling the nuclear shape seems not to be valid generally for all species. K e s s e 1 (1966) observed in the insect spermatids that the nucleus may be modelled into a cylinder also by longitudinally oriented microtubules.

The role of the manchette in modelling the spermatid nucleus seems not to be the only one, as confirmed by many authors (F a w c e t t et al. 1971; Y a s u zu mi and O ü r a 1964; Na $\mathrm{g}$ a $\mathrm{n}$ o 1962; A nde r s o $n$ and Pe r s o $n$ ne 1967; A $n$ d e r s o $n$ and E 11 is 1967). S a p s f r o d et al. (1967) and R u s s e ll et al. (1991) ascribed to it also the role of fluid transport during nuclear condensation. In poultry spermatids, this role is likely to be fulfilled by longitudinally oriented microtubules.

However, the manchette of the poultry spermatids can play other roles, and in our opinion, it is of great importance for the development of the flagellum. Some events that take place in the spermatid during its development cannot go unnoticed. There are, above all, formation of the axial bundle of fibrils, formation of mitochondrial and amorphous sheaths as well as the onset and slide of the Jensen annulus. We suggest that the manchette microtubules with elongated arrangement prevent a premature deposition of mitochondria to the distal centriole and axial bundle of fibrils prior to the Jensen annulus slide is finished and formation of the amorphous sheath is completed. It may also be involved in displacement of the cytoplasm during the process of spermatozoon maturation.

No differences among species examined were found relating to the structure and function of the manchette. 


\section{Formovanie a úloha mikrobúl manžety u spermatíd hydiny}

Formovanie mikrotubúl manžety a ich zánik pri spermatídach kohútov, kácerov a japonských prepelíc bolo študované.

Manžeta spermatíd u troch študovaných druhov pozostáva zo skupiny mikrotubúl a objavuje sa blízko predlžujúceho sa jadra spermatídy. Existuje v dvoch podobách: v prvom stádiu vývoja má podobu špirály, v druhej fáze pozostáva $\mathrm{z}$ pozdlžne usporiadaných mikrotubúl. V oboch prípadoch mikrotubuly sú usporiadané do tvaru válca ktorého celistvost môže byt narušená hlavne v oblasti bičíka. Pri špirálovitom usporiadaní manžeta pozostáva $\mathrm{z}$ jedného radu špirálovite sa akrozómu a končia v mieste konca distálného centriolu vyvíjajúceho sa bič́ka. Premena špirálovite usporiadaných mikrotubúl do pozdlžneho usporiadania je velmi rýchla a pravdepodobne sa uskutočňuje rekonštrukciou pôvodných mikrotubúl ako i syntézou nových mikrotubúl. Vytratenie sa manžety sa uskutočňuje vytratením sa mikrotubúl bez zanechania zbytkov v oblasti hlavičky a predného úseku bicíka a zanechaním zbytkov elektrón denzného materiálu v cytoplazme dozrievajúcich spermatíd. Úloha manžety so spirálovitým usporiadaním mikrotubúl je tvarovat jadro spermatídy z pôvodne okrúhleho tvaru do tvaru dlhého válca a pri pozdlžnom usporiadaní mikrotubúl pomáha pri presune cytoplazmy z prednej časti hlavičky do kaudálnych úsekov bičíka. Okrem toho manžeta pravdepodobne hrá úlohu pri formovaní mitochondriálnej pošvy bičíka spermie.

\section{References}

ANDERSON W.A., ELLIS R.A. 1967: Cytodifferentation of the crayfish spermatozoon: acrosome formation, transformation of mitochondria and development of microtubules. Z. Zellforsch. 77:80-94

ANDERSON W.A., PERSONNE P. 1967: The fine structure of the neck region of spermatozoa of Helix aspersa. J. Microscopie 8:1033-1042

BLOOM G., NICANDER L. 1961: Of the ultrastructure and development of the protoplastic droplet of spermatozoa. Z. Zellforsch. 55:833-844

BOISSON C., MATTEI X. 1966: La spermiogenese de Python sebae Gmelin obesrvee au microscope electronique. Ann. Sc. Nat. Zool. ser. 12:363-390

BRÜKELMANN J. 1963: Fine structure of germ cells during the cycle of the seminiferous epithelium in the rat. Z. Zellforsch. 59:820-850

BURGOS M.H., FAWCETT D.W.: Studies on the fine structure of the mammalian testis. I. Differentiation of the spermatids in the cat (Felis domestica). J. Biophys. Biochem. Cytol. 1:287-300

CLARK A.W. 1967: Some aspects of spermiogenesis in a lizard. Amer. J. Anat. 121:369-400

DOOHER G.B., BENNETT D. 1973: Fine structural observations on the development of the sperm head in the mouse. Amer. J. Anat. 136:339-362

FAWCETT D.W., ANDERSON W.A., PHILLIPS D.M. 1971: Morphogenetic factors influencing the shape of the sperm head. Develop. Biol. 26:220-251

GOODROWE K.L., HEATH E. 1984: Disposition of the manchette in the normal equine spermatid. Anat. Rec. 209:177-183

KESSEL R.G. 1966: The association between microtubules and nuclei during spermiogenesis in the dragonfly. J. Ultrastruct. Res. 16:293-404

MARETTA M. 1974: Disappearance of the manchette from drake spermatid. Foila morphol. (Praha) 22:256-260

McINTOSH J.R., PORTER K.R. 1967: Microtubules in the spermatids of the domestic fowl. J. Cell Biol. 35:153-173

NAGANO T. 1962: Observations on hte fine structure of the dewveloping spermatid in the domestic chicken. J. Cell Biol.

OKAMURA F., NISHIYAMA H. 1976: The early development of the tail and the transformation of the shape of the nucleus of the spermatid of the domestic fowl, Gallus gallus. Cell Tiss. Res. 169:345-359

PHILLIPS D.M. 1970: Development of spermatozoa in the woolly opossum with special reference to the shaping of the sperm head. J. Ultrastruct. Res. 33:3369-380

PLO\#N L. 1971: Scheme of rabbit spermatelioss based upon electron microscopical observations. Z. Zellforsch. 115:553-564

REGER J.M. 1967: A study on the fine strucutre of the developing spermatozoa from the oligochaete, Enchytraeus albidus. Z. Zellforsch. 82:257-269

REYNOLDS E.S. 1963: The use of lead citrate at high pH as an electron opaque stain in electron microscopy. J. Cell. Biol. 17:208-212 
ROSARIO B.J. 1964: An electron microscope study on spermatogenesis in cestodes. J. Ultrastruct. Res. 11:412-427 RUSSELL L.D., RUSSELL J.A., MacGREGOR G.R., MEISTRICH M.L. 1991: Linkage of manchette microtubules to the nuclear envelope and observations of the role of the manchette in nuclear shaping during spermiogenesis in rodents. Am. J. Anat. 192:97-120

SAPSFORD C.S., CLARE A.R., CLELAND K.W. 1967: Ultrastructural studies on spermatids and Sertoli cells during early spermiogenesis in the bandicoot Perameles nasuta Geoffroy (Marsupialia). Aust. J. Zool. 15:881909

SICKLES K.I., HEATH E.: Disposition of the manchette and related events in the feline spermatid. Anat. Rec. 216:367-372

SILVEIRA M., PORTER K.R. 1964: The spermatozoids of flatworms and their microtubular systems. Protoplasma (Wien) 59:240-265

STANLEY H.P. 1971: Fine structure of spermiogenesis in the Elasmobranch fish Squalus sucklei. II. Late stages of differentiation and structure of the mature spermatozoon. J. Ultrastruct. Res. 36:103-118

TINGARI M.D. 1973: Observation on the fine structure of spermatozoa in the testis and excurend ducts of the male fowl, Gallus domesticus. J. Reprod. Fert. 34:255-265

WERNER G. 1965: Untersuchungen über die Spermiogenese beim Sandläufer Ciciudela campestris L. Z. Zellforsch. 66:255-275

YASUZUMI G., DÜRA CH. 1964: Spermatogenesis in animals as revealed by electron microscopy. XIII. Formation of a tubular structure and two bands in the developing spermatid of the silkworm Bombyx mori L.Z. Zellforsch. 44:210-226 


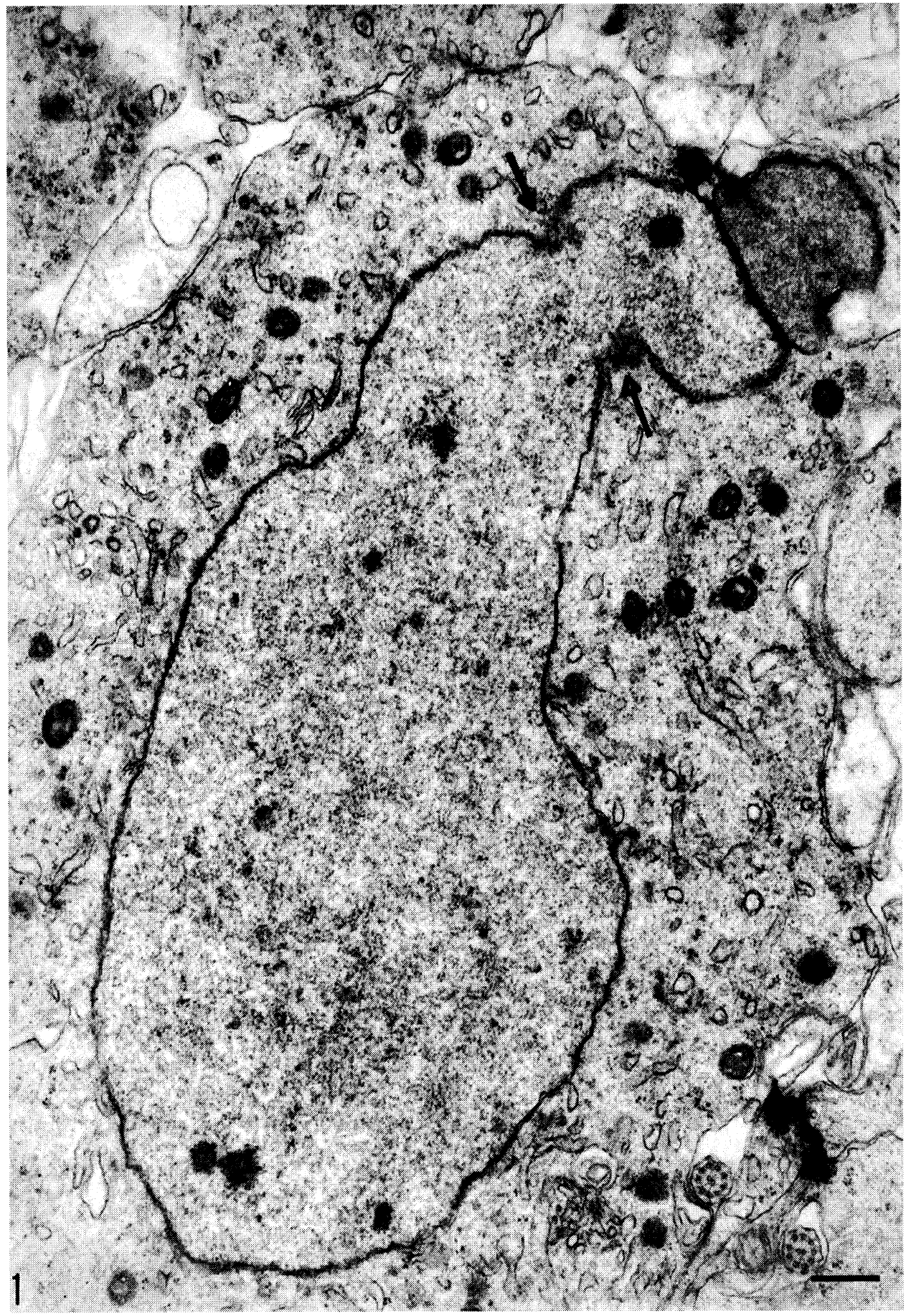

Fig. 1. Early spermatid of Japanese quail. The first appearance of the microtubules close to the nuclear membrane induced a marked constriction of the nuclear surface (arrows), the other part of the nucleus acquires an elongated shape. $\mathrm{x} 15,000$. Bar: $0.5 \mathrm{~mm}$. 

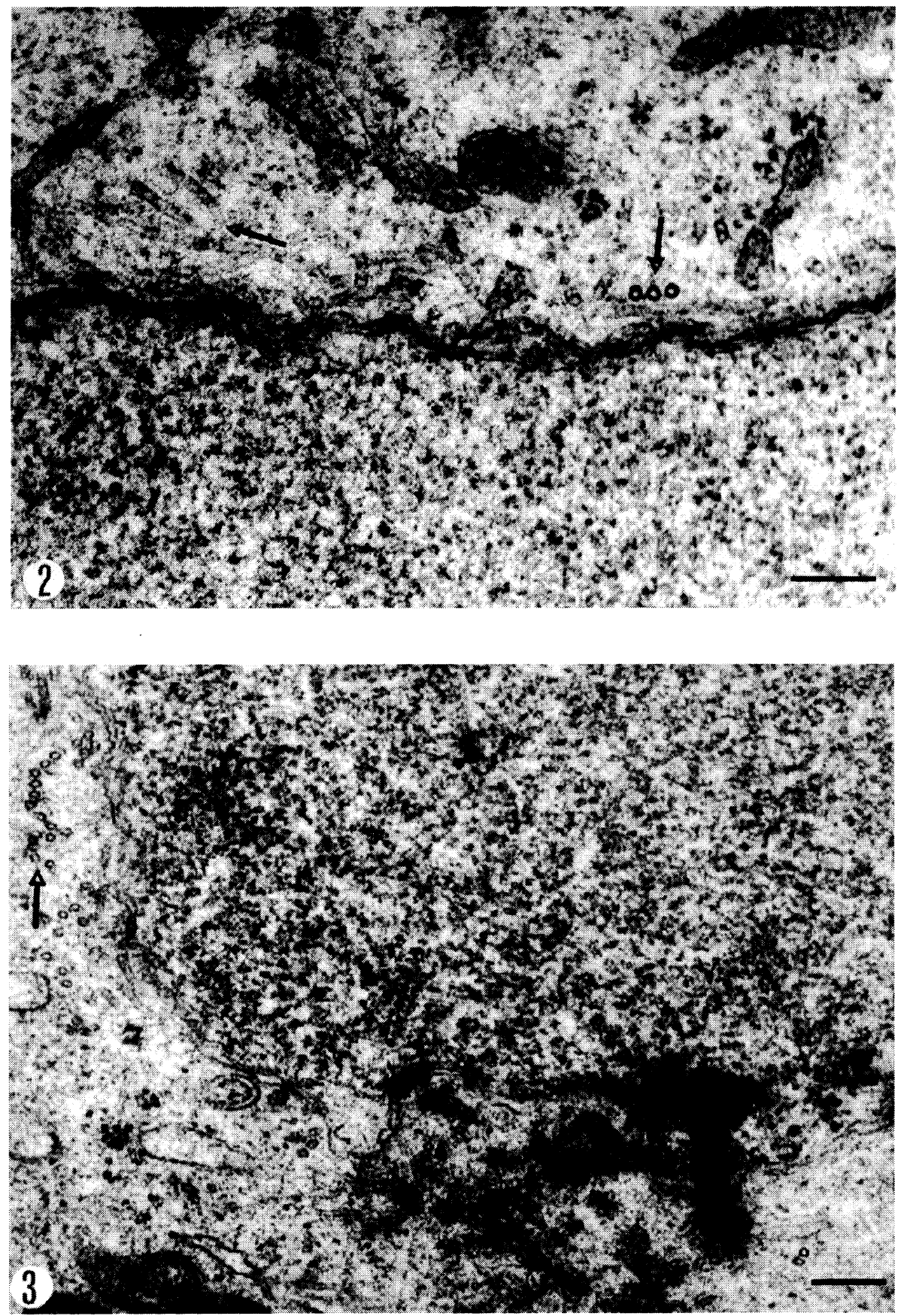

Fig. 2. A part of the cytoplasm and spermatid nucleus in Japanese quail. A large enlargement reveals some regularly, but also irregularly located microtubules very close to the nucleus (arrows). x 56,400. Bar: $0.2 \mathrm{~mm}$. 
Plate IX.
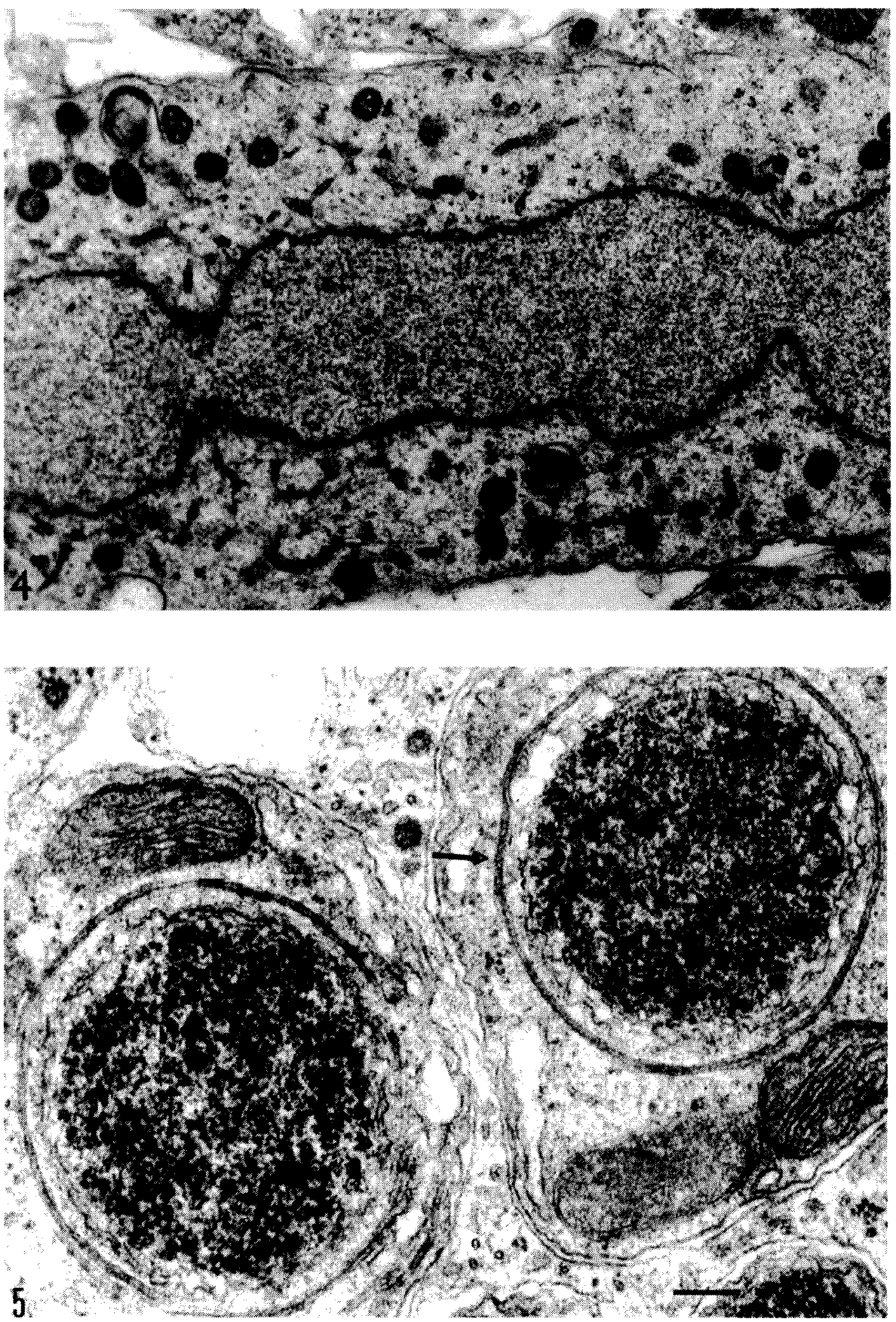

Fig. 4. Early spermatid of Japanse quail in the stage of chromatin condensation. The nucleus is already considerably elongated, and at two points markedly constricted due to microtubule accumulation. x 30,100. Bar: $0.2 \mathrm{~mm}$. Fig. 5. Early spermadits in a cock in the elongation stage. On the cross-section there is a helical arrangement of microtubules running at the same distance from the nuclear membrane of the spermatid (arrow). $x$ 45,300. Bar: $0.2 \mathrm{~mm}$. 


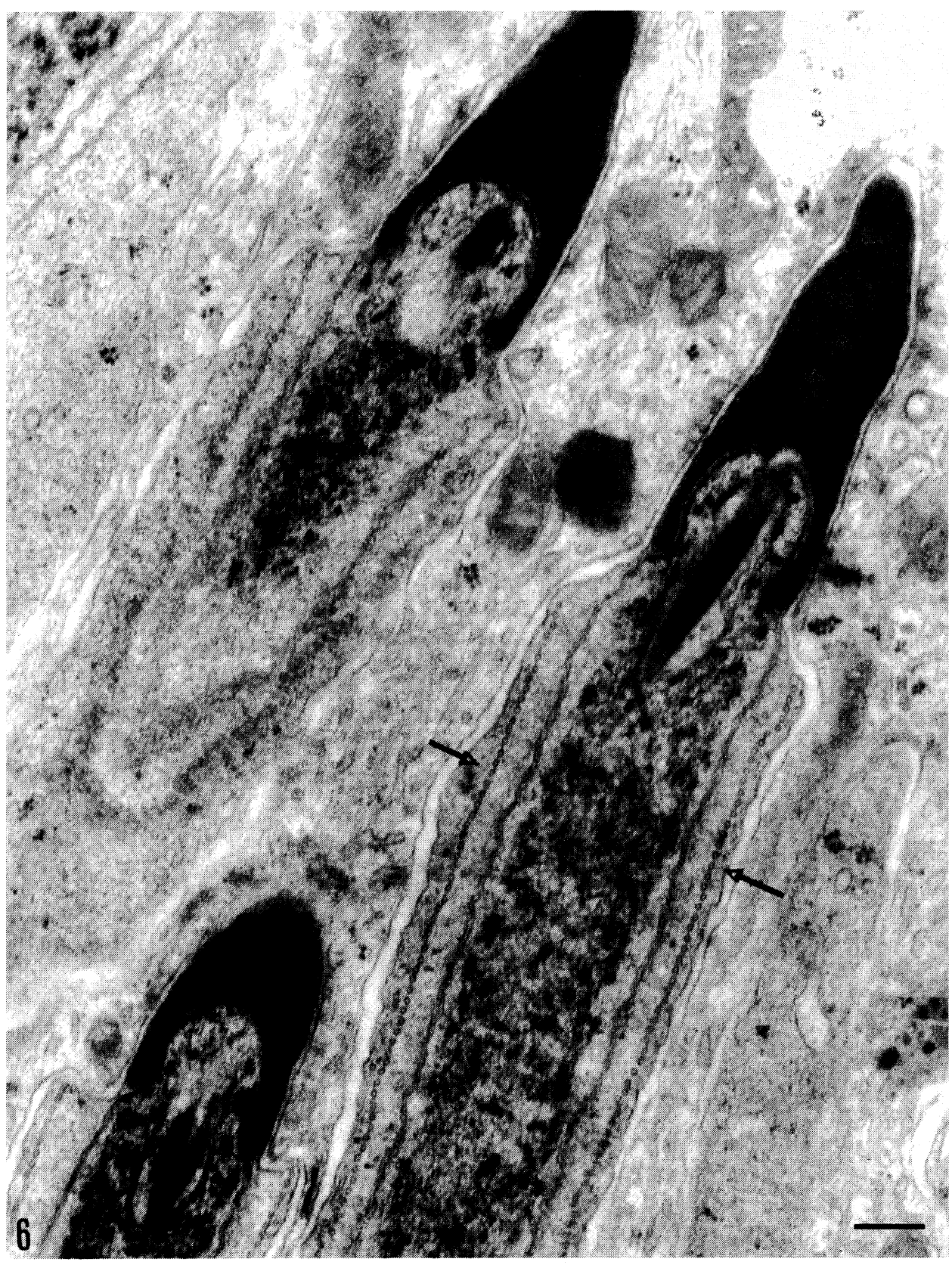

Fig. 6. Early spermatids of a cock. The manchette microtubules are arranged into one row and begin caudally from the acrosomal cap. $\mathrm{x}$ 40,000. Bar: $0.2 \mathrm{~mm}$. 

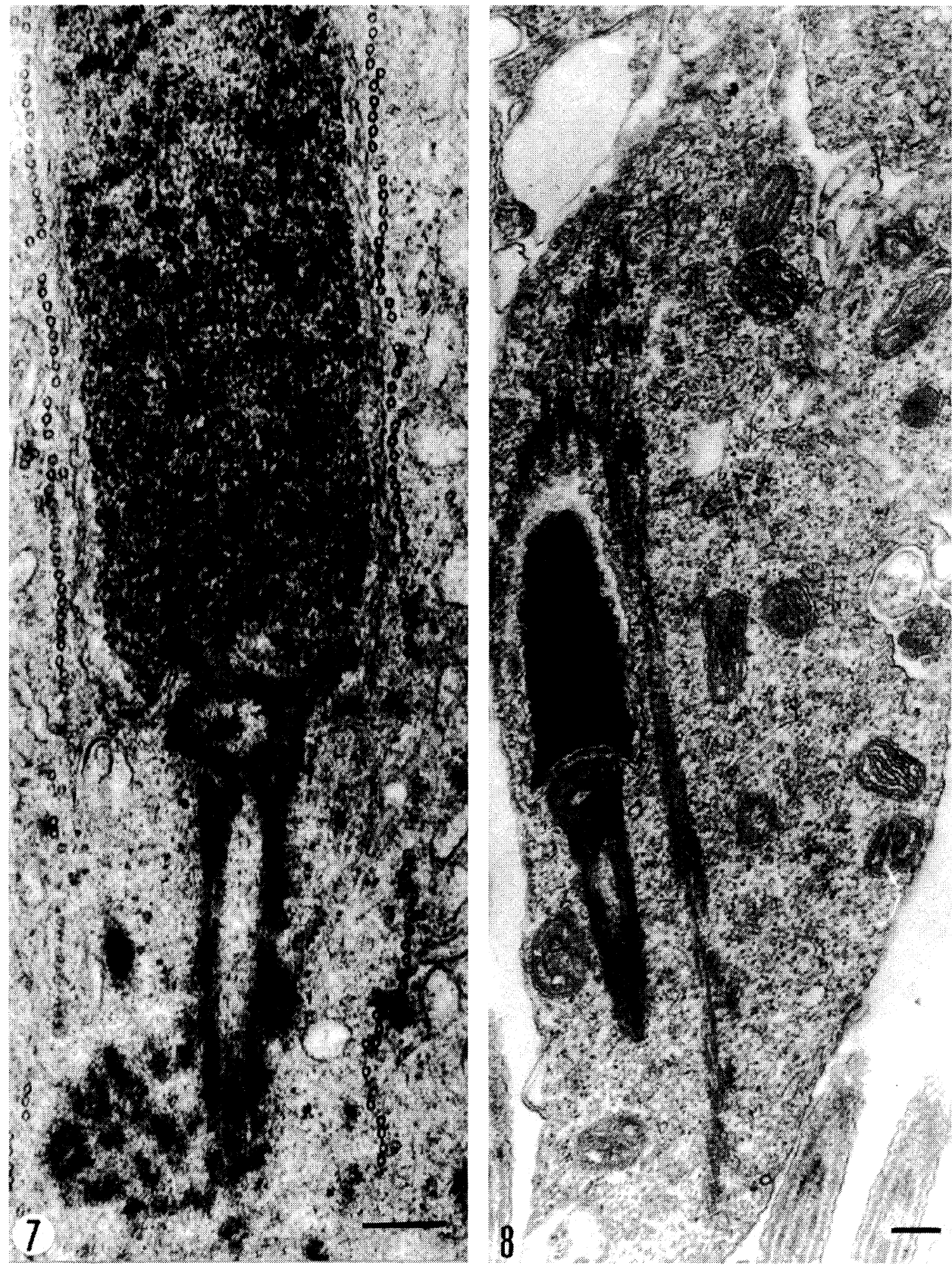

Fig. 7. Spermatids of a cock in the stage of chromatin granulation. The manchette microtubules are helical and reach the region of future middle-piece of the tail. $x$ 52,300. Bar: $0.2 \mathrm{~mm}$.

Fig. 8. Spermatid of a drake in the stage of longitudinally arrangement of the manchette microtubules. In the cytoplasm, displacement of mitochondrie to the caudal spermatid can be seen. The microtubules are abesent at the point of close mitochondria attachment to the distal centriole. $x 29,700$. Bar: $0.2 \mathrm{~mm}$. 

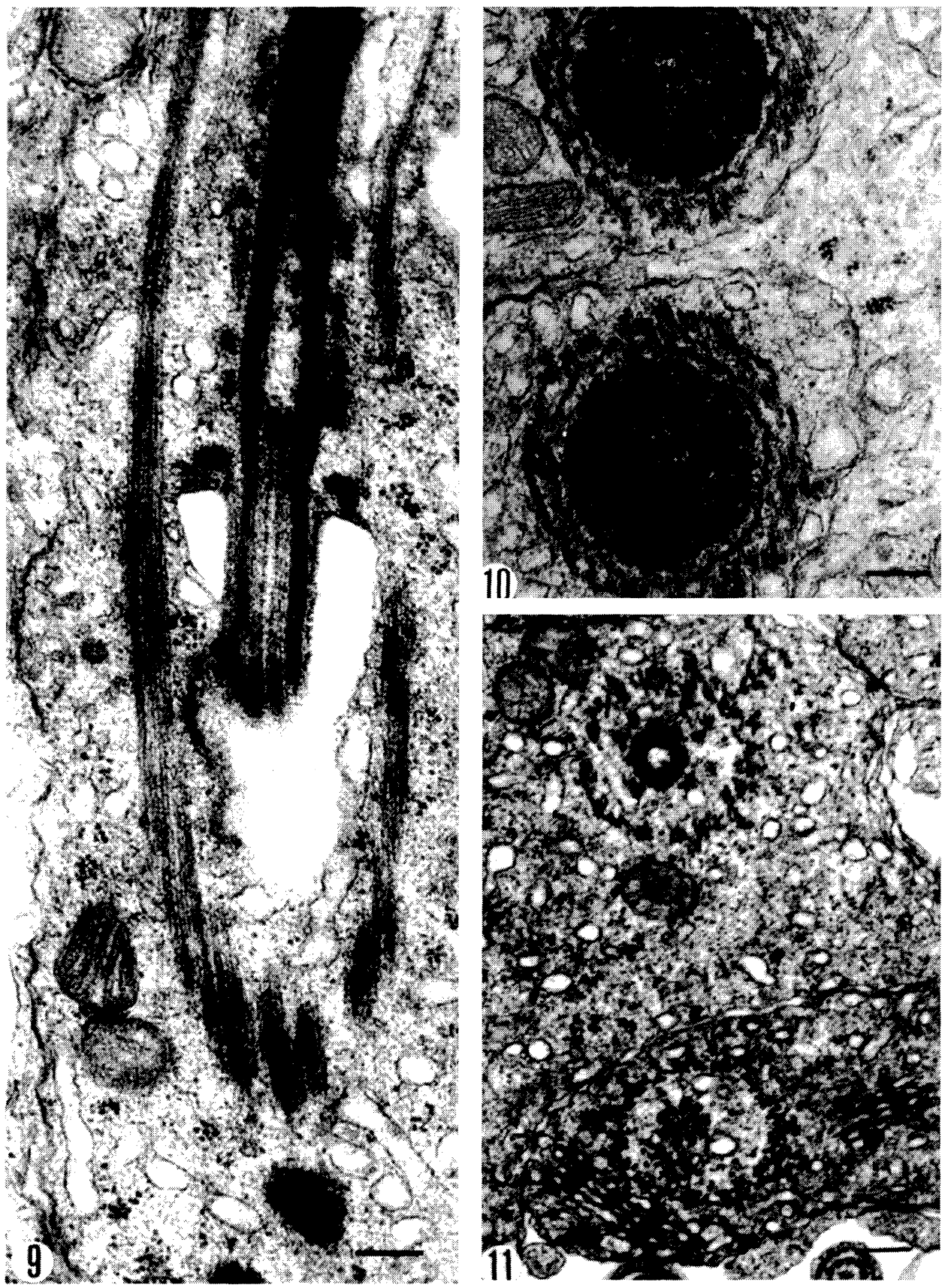

Fig. 9. A part of the forming flagellum of the drake spermatid. The microtubules run at the same distance from the distal centriole. A part of the manchette microtubules disappeared. $\times 37,800$. Bar: $0.2 \mathrm{~mm}$.

Fig.10. A cross-section through two spermatids with longitudinally arranged microtubules. The microtubules are accumulated near the nucleus and located irregularly. The nucleus has already acquired the shape of a coarse granulation. x 40,300. Bar: $0.2 \mathrm{~mm}$.

Fig.11. A cross-section through two forming flagella of the drake spermatids. The course of microtubules is almost regular within all course. $\times 36,600$. Bar: $0.2 \mathrm{~mm}$. 

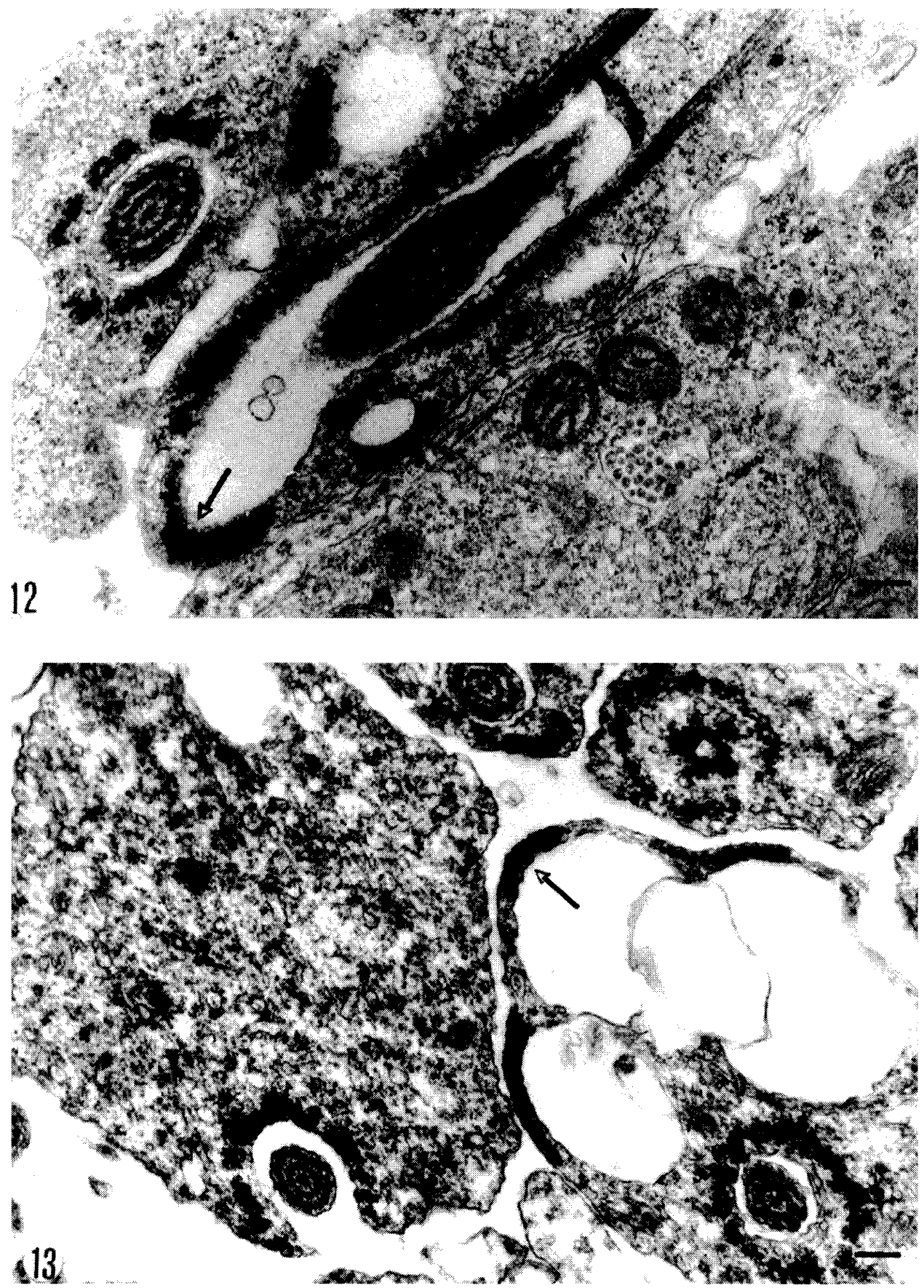

Fig.12. An oblique section from the caudal part of the spermatid flagellum in a cock. Gradual disintegration of the manchette microtubules (arrow). x 28,700.

Fig.13. A cross-section through more flagella of the drake spermatids in the marginal parts of cytoplasm (arrow) there is electron-dense material after distribution of the manchette microtubules. x 29,200. Bar: $0.2 \mathrm{~mm}$. 